\title{
KAJIAN KARAKTERISTIK DAN PENGARUH NISBAH PEREAKSI, pH AWAL REAKSI DAN SUHU REAKSI TERHADAP BERAT RENDEMEN NATRIUM LIGNOSULFONAT
}

\author{
Michael Lim, Eric Wirtanto, Zuhrina Masyithah \\ Departemen Teknik Kimia, Fakultas Teknik, Universitas Sumatera Utara, \\ Jalan Almamater, Medan 20155, Indonesia \\ Email : Michael_lim@hotmail.com
}

\begin{abstract}
Abstrak
Indonesia sebagai salah satu produsen minyak kelapa sawit terbesar di dunia tentu mengalami masalah dalam penanganan limbah kelapa sawit seperti Cangkang Kelapa Sawit. Cangkang kelapa sawit merupakan limbah industri yang memiliki nilai ekonomis yang rendah, namun memiliki kandungan lignin sebesar 29,4 \% yang sangat berpotensi sebagai bahan baku surfaktan Natrium LignoSulfonat. Natrium LignoSulfonat (NaLS) adalah surfaktan hasil sulfonasi lignin isolat dengan menggunakan $\mathrm{NaHSO}_{3}$ sebagai agen pensulfonasi. Penelitian diawali dengan mengisolasi lignin dari cangkang kelapa sawit kemudian dilanjutkan dengan reaksi sulfonasi dengan perbandingan nisbah cangkang kelapa sawit - $\mathrm{NaHSO}_{3}(\mathrm{~b} / \mathrm{b})$ 1:0,2, 1:0,3, dan 1:0,5 dan $\mathrm{pH} 6,7,8$ pada suhu $85^{\circ} \mathrm{C}$ dan $95{ }^{\circ} \mathrm{C}$. Pengidentifikasian dari pengaruh nisbah lignin cangkang kelapa sawit - $\mathrm{NaHSO}_{3}, \mathrm{pH}$ dan suhu dalam reaksi sulfonasi menunjukkan adanya perubahan terhadap berat rendemen yang dihasilkan. Namun pada kondisi seperti perbandingan nisbah pereaksi 1:0,5 dan pH 8, tidak ada perubahan signifikan yang terjadi. Berat rendemen NaLS terbaik yang dihasilkan adalah 51,2\% pada kondisi nisbah pereaksi cangkang kelapa sawit - $\mathrm{NaHSO}_{3}$ 1:0,3 , pH 7 dan suhu $95{ }^{\circ} \mathrm{C}$. Karakteristik NaLS yang dihasilkan adalah berwarna cokelat tua, Kemurnian 66,1782, pH berkisar antara 6-7 dan larut sempurna dalam air.
\end{abstract}

Kata kunci : cangkang kelapa sawit, surfaktan, lignin, natrium lignosulfonat

\begin{abstract}
Indonesia as one of the biggest producer of crude palm oil in the world for sure will have some problems on handling their wastes such as palm shell. Palm shell is one of industrial wastes that having low commercial value with contain about 29,4 \% lignin component which very potential for use as new raw material for Sodium LignoSulfonat production. Sodium lignosulphonate (SLS) is a product of isolated lignin sulphonation process using $\mathrm{NaHSO}_{3}$ as sulphonation agent.The research begins with isolated lignin from palm shell amd continued with sulphonation with mass ratio of palm shell lignin - $\mathrm{NaHSO}_{3}(\mathrm{~b} / \mathrm{b})$ of 1:0.2, 1:0.3, and 1:0.5 and initial $\mathrm{pH}$ of 6,7 and 8 at temperature 85 ${ }^{\circ} \mathrm{C}$ and $95{ }^{\circ} \mathrm{C}$. Studies on the efeect of various ratio of palm shell lignin $-\mathrm{NaHSO}_{3}$ and initial $\mathrm{pH}$ and temperature for the sulphonation raction showed an increasing yield of (SLS) yield. The highest SLS yield of 51,2 \% was obtained under condition mass ratio of palm shell lignin $-\mathrm{NaHSO}_{3} 1: 0.3, \mathrm{pH} 7$ and at temperature $95{ }^{\circ} \mathrm{C}$. The resulted SLS was dark brown, purity 66,1782, pH level between 6-7, water soluble.
\end{abstract}

Keywords : palm shell lignin, lignin, surfactant, sodium lignosulphonate

\section{Pendahuluan}

Sebagai negara penghasil minyak kelapa sawit terbesar kedua setelah Malaysia yang memiliki kapasitas produksi yang terus meningkat tiap tahunnya $(2,75 \%-29,91 \%)$, tentu saja secara tidak langsung hal ini memiliki dampak terhadap semakin banyaknya limbah yang dihasilkan, salah satunya cangkang kelapa sawit. Di Indonesia cangkang kelapa sawit sebenarnya telah banyak dimanfaatkan misalnya saja sebagai bahan baku pembuatan norit dan asap cair. Namun seiring terus bertambahnya jumlah limbah cangkang kelapa sawit, maka perlu dicari juga alternatif lain mengenai pemanfaatan cangkang kelapa sawit yang lebih efisien dan memiliki nilai ekonomis yang tinggi. Cangkang kelapa sawit memiliki komposisi lignin yang cukup besar, yaitu 29,4\% [7]. Kandungan lignin yang besar ini memungkinkan pemanfaatan cangkang kelapa sawit sebagai bahan baku olahan produk lignin menjadi Natrium Lignosulfonat melalui reaksi sulfonasi. Perumusan masalah dalam penelitian ini adalah bagaimana pengaruh antara nisbah lignin $\mathrm{NaHSO}_{3}, \mathrm{pH}$ dan suhu pada reaksi sulfonasi lignin terhadap rendemen NaLS. Tujuan dari penelitian ini adalah untuk mengamati pengaruh rasio nisbah pereaksi lignin dan $\mathrm{NaHSO}_{3}$ dan $\mathrm{pH}$ awal reaksi terhadap rendemen serta karakteristik Natrium Lignosulfonat (NaLS) dari lignin cangkang kelapa sawit. 


\section{Teori}

Surfaktan adalah senyawa organik yang memiliki setidaknya satu gugus hidrofilik dan satu gugus hidrofobik dengan bagian hidrofolik merupakan bagian yang sangat polar, sedangkan bagian hidrofobik merupakan bagian nonpolar. Surfaktan dapat dikelompokkan menjadi empat kelompok yaitu surfaktan anionik, surfaktan kationik, surfaktan non-ionik dan surfaktan amfoterik . Surfaktan mampu meningkatkan kemampuan untuk menurunkan tegangan permukaan dan antarmuka suatu cairan, meningkatkan kemampuan pembentukkan emulsi minyak dalam air dan mengubah agregasi partikel terdispersi, yaitu menghambat dan mereduksi flokulasi sehingga kestabilan partikel yang terdispersi meningkat.

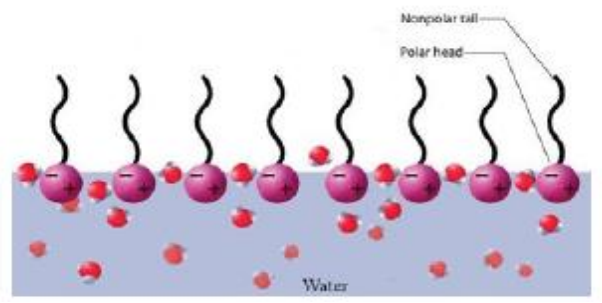

Gambar 1. Molekul Surfaktan

Sebagai salah satu jenis limbah padat hasil samping industri pengolahan kelapa sawit, Cangkang kelapa sawit masih menimbulkan permasalahan bagi lingkungan. Saat ini pemanfaatan cangkang sawit di berbagai industri pengolahan minyak CPO belum begitu maksimal.Cangkang sawit dapat diolah menjadi beberapa produk yang bernilai ekonomis tinggi, yaitu karbon aktif, fenol, asap cair, tepung tempurung dan briket arang.

Tabel 1. Data Komposisi cangkang kelapa sawit

\begin{tabular}{|l|c|}
\hline \multicolumn{1}{|c|}{ komponen } & Persen \\
\hline Lignin & $29,4 \%$ \\
Hemiselulosa & $27,7 \%$ \\
Selulosa & $26,6 \%$ \\
Air & $8 \%$ \\
Komponen ekstraktif & $4,2 \%$ \\
Abu & $0,6 \%$ \\
\hline
\end{tabular}

Proses pulping merupakan proses pelarutan lignin (delignifikasi). Proses organosolv dapat digambarkan sebagai suatu proses delignifikasi pada suhu pemasakan pulp dengan menggunakan pelarut organik. Delignifikasi pada proses organosolv disebabkan oleh terputusnya ikatan eter, yaitu $\alpha$-aril eter $(\alpha-\mathrm{O}-4)$ dan aril gliserol- $\beta$-aril eter $(\beta-\mathrm{O}-4)$ dalam molekul lignin [8]. Proses alcell adalah proses organosolv dengan menggunakan etanol sebagai bahan pemasak dengan kekuatan pulp kayu daun lebar sama dengan proses kraft.
Suhu pemasakan yang paling efektif untuk delignifikasi proses alcell berkisar pada selang antara $135-175^{\circ} \mathrm{C}$. Sherrard (1991), menyatakan bahwa proses alcell dengan campuran alkohol (etanol) dan air memiliki viskositas yang rendah pada suhu proses dan cepat menembus pada seluruh serpih kayu. Lindi hitam proses organosolv mengandung lignin dan gula-gula hemiselulosa dengan komponen paling banyak, diikuti oleh alkohol, furfural serta campuran fenol dengan bobot molekul rendah.

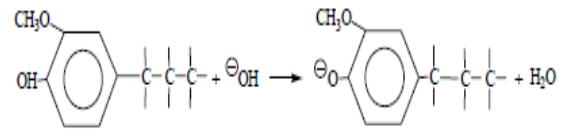

\section{Gambar 2. Reaksi lignin dan $\mathrm{NaOH}$ proses delignifikasi [1]}

Penggunaan lignin saat ini masih sangat terbatas, ini disebabkan oleh struktur kimia lignin dan kelarutannya. Lignin tidak larut dalam air, larutan asam serta larutan hidrokarbon dan hanya larut dalam alkali encer dan beberapa senyawa organik. Sifat lignin tersebut dapat diubah melalui modifikasi struktur kimia lignin misalnya dengan cara sulfonasi lignin menjadi senyawa garam lignosulfonat. Produk produk garam Lignosulfonat dapat berupa ammonium lignosulfonat, kalsium lignosulfonat, Natrium lignosulfonat dan seng lignosulfonat.

Surfaktan Natrium Lignosulfonat termasuk dalam surfaktan anionik karena memiliki gugus sulfonat dan garamnya $\left(-\mathrm{NaSO}_{3}{ }^{-}\right)$yang merupakan anion (kepala) dan gugus hidrokarbon merupakan ekor. Struktur inilah yang menyebabkan meningkatnya sifat hidrofilitas Natrium Lignosulfonat (NaLS) menjadi mudah larut dalam air sehingga penggunaan NaLS menjadi luas. Peningkatan kebutuhan industri terhadap surfaktan dan pertimbangan faktor keamanan lingkungan dan kesehatan menyebabkan surfaktan berbasis produk nabati menjadi fokus dalam mengganti surfaktan berbasis minyak bumi, contohnya seperti lignin [5] yang melalui proses sulfonasi dengan $\mathrm{NaHSO}_{3}$ dapat dijadikan sebagai surfaktan Natrium Lignosulfonat 

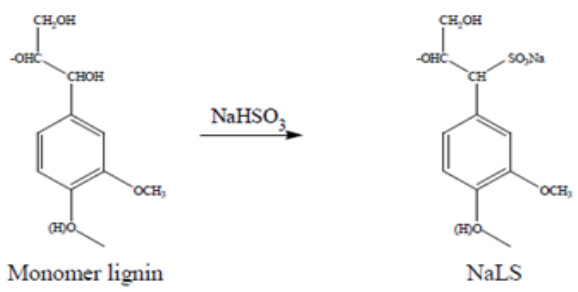

Gambar 3. Reaksi sulfonasi Lignin dengan $\mathrm{NaHSO}_{3}$

\section{Metodologi Penelitian \\ Bahan dan Alat}

Pada penelitian ini, bahan yang digunakan adalah cangkang kelapa sawit sebagai bahan bakusebagai zat pengekstrak digunakan benzene dan etanol 96\%, sebagai larutan pemasak digunakan etanol $96 \%$, air dan $\mathrm{NaOH}$, sebagai pengendap lignin dari lindi hitam digunakan $\mathrm{H}_{2} \mathrm{SO}_{4}$, sebagai bahan pensulfonasi digunakan $\mathrm{NaHSO}_{3}$ dan $\mathrm{NaOH}$ dan untuk pemurnian NaLS dari sisa $\mathrm{NaHSO}_{3}$ yang tidak bereaksi adalah methanol

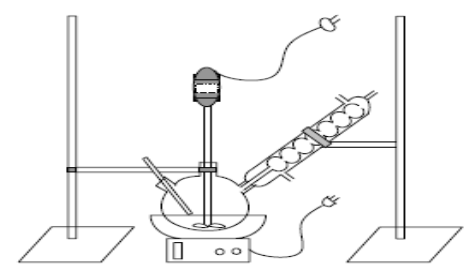

Gambar 4. Rangkaian Alat Utama

\section{Metode}

Proses pembuatan serpih cangkang bebas ekstraktif

Cangkang kelapa sawit dibersihkan, dikeringkan dengan sinar matahari kemudian digiling, kemudian dipisahkan dengan ayakan. Cangkang yang melewati ayakan kemudian dikeringakn di oven pada suhu $60^{\circ} \mathrm{C}$ hingga berat konstan. Kemudian dilakukan proses ekstraksi dengan nmenggunakan benzene : etanol 96\% (2:1 v/v) selama 6 jam. Setelah itu kemudian dikeringkan di oven pada suhu $60^{\circ} \mathrm{C}$ dan diekstraksi lagi dengan air mendidih selama 2 jam.

\section{Proses isolasi lignin}

Kondisi delignifikasi cangkang kelapa sawit adalah :

- Berat kering cangkang : 600 gr

- Larutan pemasak : 10:1 (v/b)

- Komposisi larutan pemasak etanol 96\% : air $(1: 1)$

- Katalis $\mathrm{NaOH}$ : $10 \%$ berat cangkang

- Waktu delignifikasi : 1 jam

- Suhu reaksi : $170{ }^{\circ} \mathrm{C}$
Hasil lindi hitam kemudian dititrasi sampai $\mathrm{pH}=2$ dengan asam sulfat $20 \%$ dan didiamkan selama 8 jam. Endapan yang dihasilkan kemudian dipisahkan dari filtrat dengan menggunakan kertas saring, Endapan yang dihasilkan kemudian dilarutkan dengan $\mathrm{NaOH} 1 \mathrm{~N} 100$ ml. Kemudian disaring lagi dengan menggunakan kertas saring. Filtrat kemudian dicuci dengan asam sulfat $\mathrm{H}_{2} \mathrm{SO}_{4}$ $10 \% \mathrm{v} / \mathrm{v}$ dan diikuti dengan pencucian menggunakan aquadest. Kemudian disaring dengan menggunakan kertas saring dan kemudian dikeringkan dalam oven pada suhu $55^{\circ} \mathrm{C}$ sampai mencapai berat konstan.

\section{Pembuatan Natrium Lignosulfonat}

Sebanyak 5 gr lignin dicampurkan dengan $\mathrm{NaHSO}_{3}$ dengan nisbah lignin - $\mathrm{NaHSO}_{3}(1: 0,2$, 1:0,3 dan 1:0,5) lalu disuspensikan dalam $150 \mathrm{ml}$ air. $\mathrm{pH}$ suspense kemudian dinaikkan menjadi 6,7 dan 8 dengan menggunakan larutan $\mathrm{NaOH} 15 \%$. Campuran selanjutnya direfluks pada suhu $85^{\circ} \mathrm{C}$ dan $95^{\circ} \mathrm{C}$ sambil dilakukan pengadukan dengan magnetic stirrer agar campuran reaksi sempurna dengan pemanas listrik selama 4 jam.

\section{Pemurnian}

Hasil refluks didestilasi pada suhu $100^{\circ} \mathrm{C}$ untuk menguapkan air, kemudian larutan yang telah pekat disaring dengan corong pemisah untuk memisahkan sisa lignin. Filtrat berupa NaLS yang masih mengandung $\mathrm{NaHSO}_{3}$ (sisa reaksi). Kemudian ditambahkan methanol sambil dikocok kuat sehingga $\mathrm{NaHSO}_{3}$ terendapkan dan disaring dalam corong pemisah. Metanol kemudian diuapkan dengan menggunakan refluks kondensor pada suhu $70^{\circ} \mathrm{C}$. NaLS yang diperolehdikeringkan dalam oven pada suhu $60^{\circ} \mathrm{C}$ hingga berat rendemennya

konstan.

\section{Karakteristik Natrium Lignosulfonat}

Pencirian Warna dan bau. Pencirian wana dan bau dari NaLS dilakukan secara visual.

Uji Kelarutan dalam Air. Sebanyak $0.5 \mathrm{gr}$ NaLS dimasukkan ke dalam gelas ukur $100 \mathrm{ml}$. Kemudian ditambahkan air suling mulai dari $10 \mathrm{ml}$ sampai $50 \mathrm{ml}$. Diamati kelarutan NaLS.

pH NaLS. Sebanyak 1 gram NaLS dilarutkan dengan air suling hingga $10 \mathrm{ml}$ dalam gelas ukur $25 \mathrm{ml}$, Kemudian diukur pH NaLS.

Rendemen NaLS. Rendemen adalah salah satu respon terhadap pengaruh $\left({ }^{\circ} \mathrm{C}\right), \mathrm{pH}$ dan konsentrasi sodium bisulfit pada proses sulfonasi lignin menjadi Natrium Lignosulfonat. Bobot molekul monomer lignin diasumsikan senilai 213,11 gr/mol dan dengan menggunakan persamaan-persamaan berikut

-Mol Monomer lignin (teoritis) $=\frac{\text { bobot lignin }}{B M \text { monomer }}$ 
- Rendemen NaLS $=\frac{\text { Bobot NaLS percobaan }}{\text { Bobot NaLS teoritis }} \times 100 \%$

Kemurnian. Sebanyak 0,1 gr NaLS dilarutkan dalam $100 \mathrm{ml}$ aquadest, kemudian dipipet $5 \mathrm{ml}$ larutan tersebut ke dalam gelas ukur berukuran $250 \mathrm{ml}$ dan diencerkan sampai $200 \mathrm{ml}$. $\mathrm{pH}$ larutan diatur menjadi 4 dengan penambahan $\mathrm{NaOH} 0,125 \mathrm{~N}$ atau $\mathrm{HCl} 0,2 \mathrm{~N}$. Larutan tersebut dipindahkan ke dalam labu volumetric $250 \mathrm{ml}$ dan ditetapkan volumenya dengan aquadest. Absorbans larutan diukur pada $232 \mathrm{~nm}$. Tingkat kemurnian ditentukan dengan persamaan berikut :

$\%$ tingkat kemurnian $=\frac{A 232 \times F P}{\text { Faktor } \times g \times 10}$

Keterangan:

$\mathrm{A}_{232}=$ absorbansi pada $\lambda_{232} \mathrm{~nm}$

FP $=$ Faktor pengenceran

Faktor $=$ Faktor NLS (35)

\section{Hasil}

Identifikasi lignin

Untuk melihat letak gugus fungsi dalam lignin, maka dilakukan identifikasi dengan spektrofotometer FTIR, hasil yang diperoleh adalah
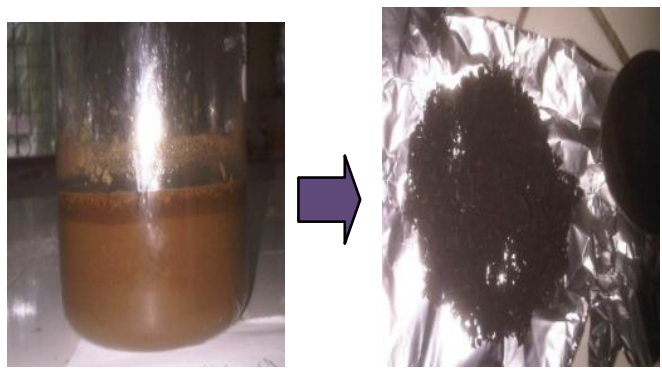

Gambar 5. Pemisahan lignin dari lindi hitam

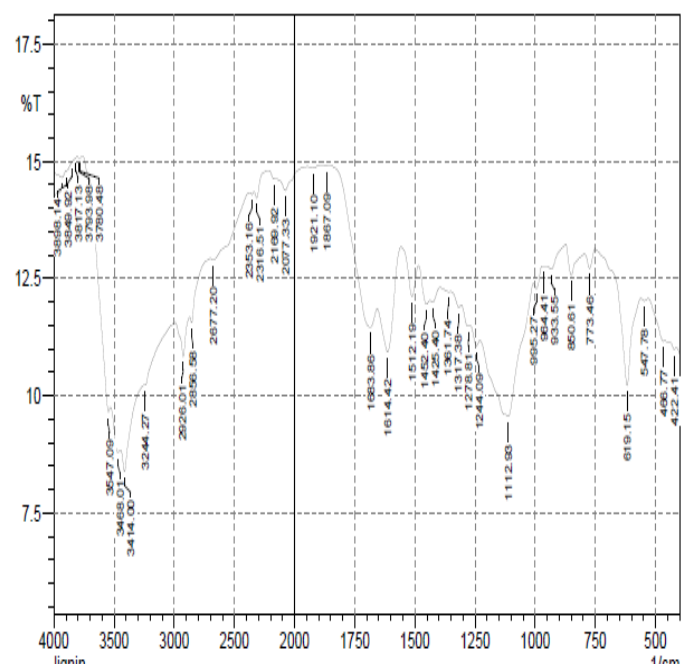

Gambar 6. Spektrum FTIR lignin
Tabel 2. Pencirian Gugus Fungsi Lignin Kraft dan Lignin Aldrich

\begin{tabular}{|c|c|c|}
\hline $\begin{array}{c}\text { Bilangan } \\
\text { Gelombang } \\
\left(\mathrm{cm}^{-1}\right)\end{array}$ & $\begin{array}{c}\text { Bilangan } \\
\text { Gelombang } \\
\left(\mathrm{cm}^{-1}\right) \\
\text { Lignin Kraft } \\
\text { Aldrich }\end{array}$ & $\begin{array}{c}\text { Gugus } \\
\text { Fungsi }\end{array}$ \\
\hline 3414.00 & 3430,62 & \\
2926,01 & 2930,17 & Uluran O-H \\
- & - & Uluran C-H metil \\
& 1599,14 & Regangan CO tak \\
terkonjugasi \\
1614,42 & 1506,78 & Vibrasi Cincin Aromatik \\
1512,19 & 1460,89 & C-H Asimetri \\
1444,68 & - & Vibrasi Cincin Siringil \\
- & 1216,15 & Vibrasi Cincin Guaiasil \\
1238,30 & 1043,50 & Uluran Eter \\
1118,71 & 853,45 & Vibrasi C-H aromatik \\
846,75 & & diluar bidang \\
\hline
\end{tabular}

Dari Hasil yang diperoleh di atas, dapat disimpulkan bahwa hasil yang diperoleh adalah lignin.

\section{Identifikasi Natrium Lignosulfonat}

Untuk melihat letak gugus fungsi dalam Natrium Lignosulfonat, maka dilakukan identifikasi dengan spektrofotometer FTIR, hasil yang diperoleh adalah

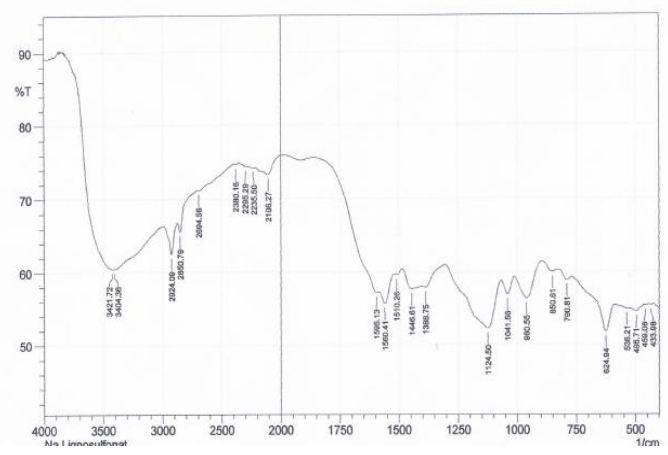

Gambar 7. Spektrum FTIR NaLS

Tabel 3. Pencirian Gugus Fungsi NaLS Kraft dan NaLS Aldrich

\begin{tabular}{|c|c|c|}
\hline Bilangan & Bilangan & \\
\hline $\begin{array}{c}\text { Gelombang } \\
\left(\mathrm{cm}^{-1}\right) \\
\text { NaLS } \\
\text { Cangkang }\end{array}$ & $\begin{array}{c}\text { Gelombang } \\
\left(\mathrm{cm}^{-1}\right) \\
\text { NaLS } \\
\text { Aldrich }\end{array}$ & $\begin{array}{l}\text { Gugus } \\
\text { Fungsi }\end{array}$ \\
\hline 3421,72 & 3423,36 & Uluran $\mathrm{O}-\mathrm{H}$ \\
\hline 2924,09 & 2935,88 & Uluran C-H metil \\
\hline 1595,1 & 1603,97 & $\begin{array}{l}\text { Vibrasi Cincin } \\
\text { Aromatik }\end{array}$ \\
\hline 1510,26 & 1510,25 & $\begin{array}{l}\text { Vibrasi Cincin } \\
\text { Aromatik }\end{array}$ \\
\hline 1446,61 & 1458,77 & Uluran $\mathrm{C}-\mathrm{H}$ gugus metil \\
\hline 1124,50 & 1140,03 & Vibrasi Gugus Sulfonat \\
\hline 1041,56 & 1040,71 & Regangan $\mathrm{S}=\mathrm{O}$ Simetri \\
\hline 960,55 & 914,05 & Regangan S-O \\
\hline 850,61 & 814,68 & $\begin{array}{c}\text { Vibrasi C-H Aromatik } \\
\text { diluar }\end{array}$ \\
\hline 624,94 & 652,76 & Uluran S-O \\
\hline
\end{tabular}


Dari hasil di atas, dapat disimpulkan bahwa hasil sulfonasi lignin menjadi NaLS telah berhasil Identifikasi Karakteristik NaLS cangkang kelapa sawit

Tabel 4. Karakteristik NaLS cangkang

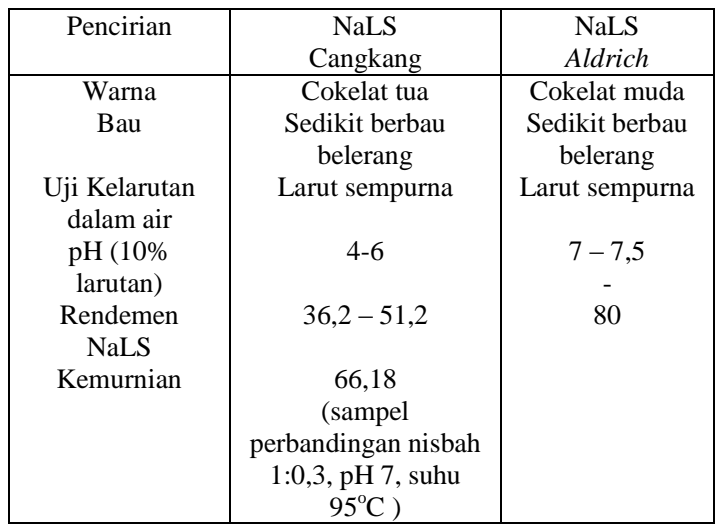

\section{Warna dan Bau}

NaLS dari limbah cangkang kelapa sawit ini berbentuk serbuk yang agak kasar dengan warna cokelat tua, namun sedikit lebih terang dibandingkan lignin cangkang kelapa sawit. Perubahan ini terjadi karena adanya gugus sulfonat pada struktur NaLS berupa ikatan rangkap dan juga diperkuat dengan bau belerang pada produk yang dihasilkan

\section{pH}

Pengukuran $\mathrm{pH}$ bertujuan untuk mengetahui derajat keasaman NaLS yang dihasilkan. pH NaLS merupakan ukuran jumlah ion hydrogen dalam Natrium Lignosulfonat yang dihasilkan daari reaksi sulfonasi lignin. Pengaruh nisbah pereaksi lignin $(1: 0,2,1: 0,3,1: 0,5)$ dan $\mathrm{pH}$ awal reaksi 6,7 dan 8 memberikan $\mathrm{pH}$ berkisar antara 4-6.

\section{Rendemen Natrium Lignosulfonat}

Berat rendemen adalah salah satu parameter untuk mengetahui jumlah NaLS yang dihasilkan dari reaksi sulfonasi lignin dengan $\mathrm{NaHSO}_{3}$. Hasil rendemen $\mathrm{NaLS}$ yang diperoleh berkisar antara $36,3-51,2 \%$. Berikut adalah hasil mengenai hubungan berat rendemen terhadap variasi nisbah pereaksi lignin cangkang kelapa sawit $-\mathrm{NaHSO}_{3}$, $\mathrm{pH}$ dan suhu awal reaksi

\section{- Hubungan Nisbah Pereaksi Lignin - $\mathrm{NaHSO}_{3}$ terhadap Berat Rendemen}

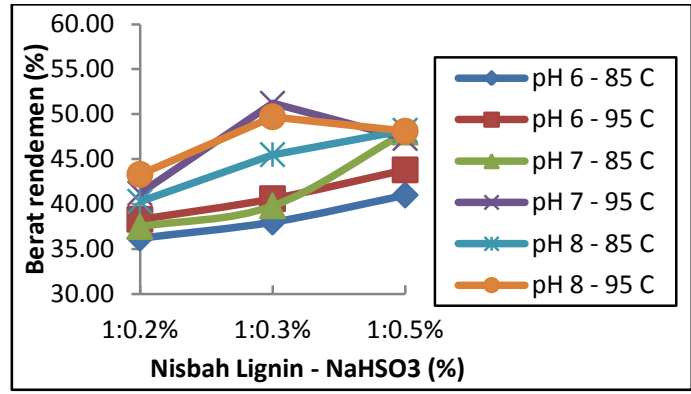

Gambar 8. Nisbah Pereaksi Lignin - $\mathrm{NaHSO}_{3}$ terhadap berat rendemen NaLS

Dapat dilihat bahwa berat rendemen cenderung semakin meningkat seiring dengan meningkatnya perbandingan Nisbah Pereaksi Lignin terhadap $\mathrm{NaHSO}_{3}$. Namun pada beberapa kondisi seperti pada $\mathrm{pH} 7-95^{\circ} \mathrm{C}$ dan pada $\mathrm{pH} 8-95^{\circ} \mathrm{C}$, berat rendemen NaLS menurun pada saat Nisbah Lignin - $\mathrm{NaHSO}_{3}$ 1:0,5\%. Peningkatan berat rendemen seiring dengan meningkatnya perbandingan Nisbah pereaksi lignin - $\mathrm{NaHSO}_{3}$ disebabkan karena dengan meningkatnya nisbah pereaksi, frekuensi terjadinya tumbukan atau interaksi antar lignin dan $\mathrm{NaHSO}_{3}$ semakin meningkat, sehingga menyebabkan masuknya gugus sulfonat $\left(-\mathrm{SO}_{3}\right)$ dari garamnya mensubstitusi gugus hidroksil ($\mathrm{OH})$ pada karbon benzilik dari lignin juga semakin sempurna. Dimana kecepatan reaksi kimia berhubungan erat dengan tumbukan antar molekul pereaksi yang membentuk produk [11].

Pada kondisi $\mathrm{pH} 7-95^{\circ} \mathrm{C}$ dan pada $\mathrm{pH} 8-95^{\circ} \mathrm{C}$, berat rendemen $\mathrm{NaLS}$ menurun pada saat Nisbah Lignin - $\mathrm{NaHSO}_{3}$ 1:0,5\%, ini disebabkan karena telah terjadi kejenuhan atau kemampuan masuknya gugus sulfonat menggantikan gugus hidroksil ($\mathrm{OH})$ pada lignin telah mencapai maksimum.

\section{- Hubungan Nisbah pH awal reaksi terhadap Berat Rendemen}

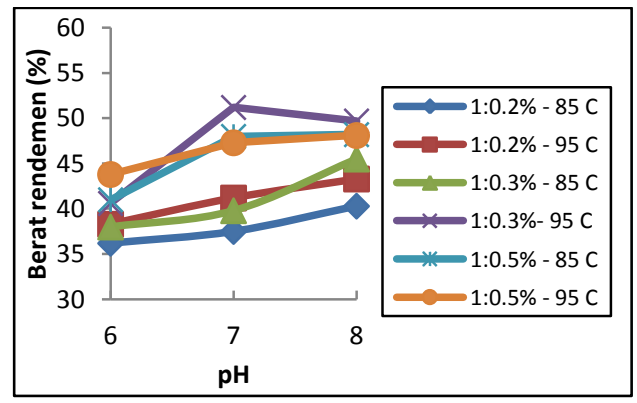

Gambar 9. pH terhadap berat rendemen NaLS

Dapat dilihat bahwa berat rendemen cenderung meningkat seiring dengan meningkat seiring dengan naiknya $\mathrm{pH}$. Namun pada beberapa kondisi seperti pada perbandingan nisbah lignin $\mathrm{NaHSO}_{3} 1-0.3 \%, 95^{\circ} \mathrm{C}$ dan pada perbandingan 
nisbah lignin - $\mathrm{NaHSO}_{3} 1-0.5 \%, 85^{\circ} \mathrm{C}$ berat rendemen pada $\mathrm{pH} 8$ mengalami penurunan atau tidak mengalami perubahan yang signifikan dibandingkan dengan kondisi pada $\mathrm{pH}$ 7. Semakin bertambah nisbah pereaksi maka tingkat kemurnian NaLS yang dihasilkan semakin tinggi. Demikan pula dengan $\mathrm{pH}$ awal reaksi, yakni semakin tinggi $\mathrm{pH}$ awal reaksi maka semakin bertambah tingkat kemurnian NaLS yang dihasilkan. Semakin tinggi $\mathrm{pH}$ awal reaksi, maka akan semakin meningkatkan kelarutan lignin. Kelarutan lignin yang bertambah akan memperluas luas permukaan lignin yang bereaksi dengan $\mathrm{NaHSO}_{3}$ dan selanjutnya akan memperbesar peluang terjadinya tumbukan antar molekul sehingga rendemen bertambah [11].

Berdasarkan teori dapat disimpulkan secara umum hasil penelitian yang dilakukan telah sesuai dengan teori yang ada. Namun pada beberapa kondisi seperti 1:0,3\% suhu $95^{\circ} \mathrm{C}$ berat rendemen pada $\mathrm{pH} 8$ cenderung turun dari kondisi $\mathrm{pH}$ 7. Hal ini disebabkan karena kelarutan lignin yang sudah jenuh, sehingga berat rendemen cenderung tidak meningkat lagi.

\section{- Hubungan Suhu reaksi terhadap Berat Rendemen}

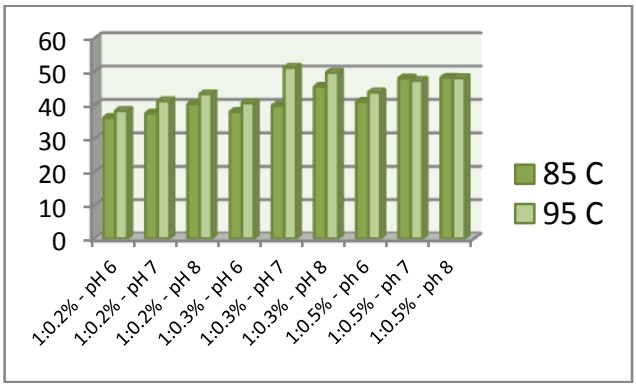

Gambar 10. Temperatur terhadap berat rendemen

Dapat dilihat bahwa berat rendemen cenderung naik seiring dengan meningkatnya suhu reaksi, yaitu dari $85^{\circ} \mathrm{C}$ dan $95^{\circ} \mathrm{C}$. Namun pada kondisi perbandingan nisbah pereaksi 1:0,5\%, pH 7 dan perbandingan nisbah pereaksi 1:0,5\%, $\mathrm{pH}$ 8, berat rendemen mengalami penurunan meskipun tidak signifikan. Berdasarkan teori, peningkatan suhu dapat menyebabkan peningkatan energy akitivasi. Hal ini menyebabkan banyak molekul yang memiliki energi pengaktif sehingga semakin banyak tumbukan antar molekul yang terjadi dan terus berlanjut terjadi dalam reaksi sulfonasi. Semakin banyak tumbukan antar molekul akan menyebabkan berat rendemen yang juga semakin tinggi [11].

Berdasarkan teori dapat disimpulkan secara umum hasil yang diperoleh telah sesuai dengan teori yang ada, Namun pada kondisi perbandingan nisbah pereaksi 1:0,5\%, pH 7 dan perbandingan nisbah pereaksi 1:0,5\%, $\mathrm{pH} 8$, berat rendemen mengalami penurunan. Hal ini disebabkan karena telah terjadi kejenuhan tumbukan antar molekul yang menyebabkan berat rendemen tidak lagi mengalami peningkatan.

\section{Kesimpulan}

- Cangkang kelapa sawit dapat dijadikan sebagai alternatif dalam pembuatan Natrium Lignosulfonat karena hasil sulfonasi lignin cangkang kelapa sawit berupa Natrium Lignosulfonat yang diperoleh telah sesuai dengan karakteristik yang dijual di pasaran

- Hasil kajian pengaruh nisbah lignin cangkang kelapa sawit - $\mathrm{NaHSO}_{3}(1: 0,2,1: 0,3)$, pH $(6,7)$ dan suhu $95{ }^{\circ} \mathrm{C}$ memberikan nilai berat rendemen yang semakin meningkat, sedangkan pengaruh nisbah pereaksi cangkang kelapa sawit 1:0,5 , pH 8 dan suhu $85^{\circ} \mathrm{C}$ tidak menunjukkan perbedaan yang signifikan terhadap berat rendemen yang dihasilkan.

- Kondisi terbaik diperoleh ketika perbandingan nisbah pereaksi 1:0,3, pH 7 dan suhu $95^{\circ} \mathrm{C}$ dengan berat rendemen sebesar 51,2\% dan kemurnian 66,1782\%.

- Karakteristik NaLS yang dihasilkan, mempunyai warna cokelat tua, larut dalam air, $\mathrm{pH}$ 4-6 dan sedikit berbau belerang.

\section{Daftar Pustaka}

[1] Heradewi, Isolasi lignin lindi hitam dari pemasakan organosolv serat tandan kosong kelapa sawit. Tesis. Fakultas Teknologi Pertanian Institut Pertanian Bogor, 2007.

[2] Ismiyati. Pembuatan Natrium Lignosulfonat berbahan dasar ligni isolate tandan kosong kelapa sawit: Identifikasi dan uji kinerjanya sebagai bahan pendispersi. Jurnal. Program studi Teknik Kimia, Universitas Muhammadiyah Jakarta , 2009.

[3] Syahbirin Gustini, Pengaruh Nisbah Pereaksi (lignin Eucalyptus - Natrium Bisulfit) dan $\mathrm{pH}$ awal reaksi terhadap karakteristik Natrium Lignosulfonat. Jurnal. Institut Pertanian Bogor, 2009.

[4] Foster NC.1997. Sulfonation and Sulfation Processes. The Chemithon Corporation, www.chemithon.com, diakses tanggal 23 April 2012

[5] Collepardi M, Chemical Admixtures Today. Proceedings of Second International Symposium on Concrete Tecnology for Sustainable February - Development with EmpHasis on Infrastructure; 
Ponzano Veneto (Italy), 27 February-3 March 2005. hlm 527-541

[6] Douglas C. J., Phenylpropanneoid metabolism and lignin brosynthesis : from weed to trees.Trends Plant Sci. 1:171-178, 1996.

[7] Suhardiyono, L, Tanaman Kelapa, Budidaya dan Pemanfaatannya, Penerbit Kanisius, Yogyakarta, 153-156, 1988.

[8] Sundquist, J. Organosolv Pulping. Chemical Pulping at Paper making Science and Technology, Helsinky Finland, 1999.

[9] Sykes, P, A Guidebook to Mechanism in Organic Chemistry, 1989.

[10] Sherrad, E. Alcell Can Offer a Green Solution. J. Tappi. 74 (10), April 1991, tidak dipublikasikan. 